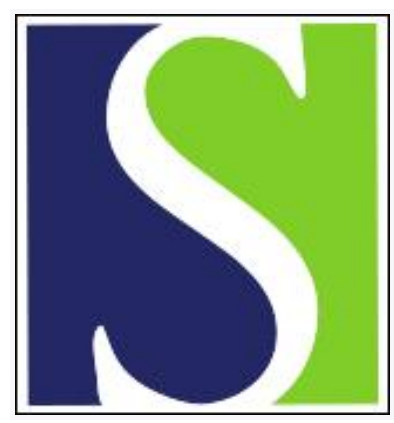

Scand J Work Environ Health 2008;34(5):387-395

https://doi.org/10.5271/sjweh.1285

Issue date: 00 Oct 2008

Development of an obeche wood allergen quantification assay for the assessment of allergen exposure in workplaces

by Kespohl S, Sander I, Schulze J, Poppe M, Brüning T, Raulf-Heimsoth $\mathrm{M}$

Affiliation: BGFA-Forschungsinstitut für Arbeitsmedizin der Deutschen Gesetzlichen Unfallversicherung, Ruhr-Universität Bochum, Allergologie / Immunologie, Bürkle-de-la-Camp Platz 1, 44789 Bochum, Germany. kespohl@bgfa.de

Key terms: aeroallergens; allergen; allergen exposure; assessment; exposure assessment; obeche wood allergen; occupational allergy; quantification assay; wood allergen; wood dust exposure; workplace

This article in PubMed: www.ncbi.nlm.nih.gov/pubmed/18956126 


\title{
Development of an obeche wood allergen quantification assay for the assessment of allergen exposure in workplaces
}

\author{
by Sabine Kespohl, PhD, ${ }^{1}$ Ingrid Sander, PhD, ${ }^{1}$ Johannes Schulze, PhD, ${ }^{2}$ Marnix Poppe, MS, ${ }^{2}$ Thomas \\ Brüning, MD, ${ }^{1}$ Monika Raulf-Heimsoth, $P h D^{1}$
}

\begin{abstract}
Kespohl S, Sander I, Schulze J, Poppe M, Brüning T, Raulf-Heimsoth M. Development of an obeche wood allergen quantification assay for the assessment of allergen exposure in workplaces. Scand J Work Environ Health 2008;34(5):387-395.
\end{abstract}

Objectives The purpose of this study was to develop a quantification assay to measure airborne concentrations of obeche wood allergen at workplaces.

Methods Specific polyclonal antibodies to obeche wood were produced in rabbit and used to develop an inhibition enzyme immunoassay (EIA). Inhalable dust samples from three wood-processing companies were taken with a stationary sampling device (Gravicon VC25). The loaded dust filters were extracted under standardized conditions and measured with the assay. In addition, the antigen and allergen contents of obeche wood from different sources (Cameroon, $\mathrm{N}=5$; Ghana, $\mathrm{N}=4$ ) were analyzed from immunoblots, detected with rabbit immunoglobulin (Ig) $\mathrm{G}$ and human Ig E.

Results Polyclonal antibodies specific for obeche wood allergens, without cross-reactivity to other woods, were used to establish the inhibition enzyme immunoassay. The assay is able to quantify allergen concentrations from 30 to $300 \mathrm{ng} / \mathrm{ml}$. With inhibition enzyme immunoassay, exposure to airborne obeche wood allergen can be monitored in wood-processing companies. Inhalable dust samples from workplaces contained an average allergen concentration of $15 \mu \mathrm{g} / \mathrm{g}$ dust. Significantly lower protein and allergen contents were measured for obeche wood from Cameroon (ayous) in one company. IgE immunoblots indicated that the lower antigen and allergen contents of the ayous wood may be the result of its lacking the major obeche wood allergen, Trip s 1.

Conclusions The data showed that the total dust concentration in workplaces containing obeche wood dust did not correspond to the assessed allergen concentration. To estimate exposure limits regarding sensitization risk, it is necessary to measure the allergen content directly.

Key terms aeroallergens; occupational allergy; quantification assay; wood dust exposure.

Occupational exposure to wood dust has been shown to be associated with health problems, including nasal cancer and respiratory or pulmonary symptoms caused by allergenic or irritative agents (1-4). In Germany about 700000 workers are occupationally exposed to inhalable wood dust. According to estimates, $25 \%$ of workers are exposed to 2-5 mg of wood dust $/ \mathrm{m}^{3}$ air, and $15 \%$ are exposed to even higher concentrations than $5 \mathrm{mg} / \mathrm{m}^{3}(2)$. To protect exposed workers from the harmful effects of wood dust, the member states of the European Union set an occupational exposure limit (OEL) of $2 \mathrm{mg} / \mathrm{m}^{3}$ for inhalable dust per cubic meter of ambient air. In 2002, the Scientific Committee for Occupational Exposure
Limits proposed a lower wood dust concentration of $0.5 \mathrm{mg} / \mathrm{m}^{3}$ as the limit for avoiding pulmonary effects during work. Subsequently, a controversial discussion on a health-based exposure limit for wood dust began (5). However, the lower limit, which was intended to prevent health risks, cannot be recommended with respect to the prevention of allergic diseases and the risk of sensitization to wood dust. In regard to the occupational exposure limit for allergens, the situation is more difficult because individual susceptibility varies, unlike the situation for toxic substances, which affects all exposed persons equally. In estimating the relationship between wood dust exposure, allergen concentration, and health

1 BGFA—Research Institute of Occupational Medicine, German Social Accident Insurance, Ruhr-University Bochum, Germany.

2 Holz-BG, München, Germany.

Reprint requests to: Dr Sabine Kespohl, BGFA—Forschungsinstitut für Arbeitsmedizin der Deutschen Gesetzlichen Unfallversicherung, Ruhr-Universität Bochum, Allergologie / Immunologie, Bürkle-de-la-Camp Platz 1, 44789 Bochum, Germany. [Email: kespohl@bgfa.de] 
effects, it is important to assess the allergen concentrations, not merely the total wood dust concentrations. Allergic symptoms elicited by airborne occupational allergens often start with rhinitis in the upper airways, which can proceed to the lower respiratiory tract and cause asthma (6-8). Especially in the wood-processing industry, for which several of respiratory symptoms have been described, an assessment of sensitizing wood dust components is very important in helping to prevent the development of severe respiratory problems among sensitized workers and in carrying out allergen reduction strategies at such workplaces.

Wood workers are normally exposed to a variety of different soft and hard woods. Wood dust of the tropical obeche tree (Triplochiton scleroxylon) was reported as a strong sensitizer for allergy mediated by immunoglobulin $(\operatorname{Ig}) \mathrm{E}(9,10)$. In contrast to other wood species that act predominantly as type-IV sensitizers, obeche wood has a high protein content but no, or only low, concentrations of quinone and lapachol (11), and this difference may explain its dominant role as an allergy type I sensitizer. In addition, Trip s 1, identified from obeche wood (12), was the first characterized and denominated wood allergen (www.allergome.org). The main applications of obeche wood are in sauna-building, as chamfer strips in concrete formwork, picture frames and, due to its light weight, slats for caravans and model building. Even though obeche wood is not processed to a great extent, due to its high allergenic potency, it is a good model system for establishing an allergen quantification assay for use at workplaces with exposure to wood dust. The application of this allergen quantification assay allows the identification of risk sites and offers the possibility to monitor the success of allergen reduction and avoidance strategies.

\section{Material and methods}

\section{Allergen extraction for obeche wood dust}

Obeche wood extract, prepared from freshly ground material of certified origin and without preservatives from Ghana, Africa (Theodor Schumacher, Söhne Holzhands $\mathrm{GmbH}$, Cologne, Germany), served as a standard. Furthermore, obeche wood samples were taken from three companies processing obeche wood from Ghana and Cameroon. The declaration of origin was given by the company and could not be further certified. Wood dust was mixed 1:10 (weight/volume) with phosphate-buffered saline (PBS, pH 7.4) containing $0.5 \mathrm{mM}$ Pefablock (Serva, Heidelberg, Germany) and 2\% polyvinylpolypyrrolidone (Sigma, Deisenhofen, Germany) and gently stirred for 16 hours at $4^{\circ} \mathrm{C}$. After extraction, the suspen- sion was centrifuged $\left(15000 \mathrm{~g}, 4^{\circ} \mathrm{C}\right)$ for 45 minutes, and the supernatant containing soluble wood-dust proteins was dialyzed against distilled water (Spektra / Por, $3.5 \mathrm{kD}$ MWCO, Serva) and lyophilized. The protein concentration was quantified with BIO-RAD protein assay (BIO-RAD, München, Germany) using albumin bovine fraction $\mathrm{V}$ (Serva) as a standard.

\section{Polyclonal antiserum specific for obeche wood}

Antibodies specific for obeche wood were produced in a New Zealand white rabbit, which was immunized with obeche wood protein extract $(0.5 \mathrm{mg} / \mathrm{ml})$ suspended in Titermax Gold adjuvant (Sigma). To improve immune response, the rabbit was boosted with the same antigen in PBS 5 weeks after the initial injection. Antigen-specific polyclonal antibodies were obtained in the whole blood fraction, which was taken 12 weeks after the immunization by centrifugation for 20 minutes at $2000 \mathrm{~g}$ at room temperature. The polyclonal rabbit serum was stored in aliquots at $-70^{\circ} \mathrm{C}$ until use.

\section{Human sera specific for obeche wood}

Serum samples from six men with a physician-diagnosed allergy to obeche wood were used for the IgE detection. All of the men had been exposed to obeche wood in the wood-processing industry, and they reported workrelated asthma and had positive skin prick tests with obeche. They also had obeche-specific IgE in the range of $9.52 \mathrm{kU} / \mathrm{l}$ to $25.40 \mathrm{kU} / \mathrm{l}$ (median value: $20.25 \mathrm{kU} / \mathrm{l}$ ) according to obeche-wood-specific ImmunoCAPs (k212, Phadia, Uppsala, Sweden). Equal amounts of sera were mixed to generate the obeche-wood-specific serum pool (obeche-specific IgE: $19.6 \mathrm{kU} / \mathrm{l}$ ).

\section{Electrophoresis and immunoblotting}

Wood extract proteins were separated by SDS-PAGE (sodium dodecyl sulfate-polyacrylamide gel electrophoresis) using precasted NuPAGE gels (Novex, San Diego, CA, USA) in a Novex Xcell II mini-cell unit according to the manufacturer's instructions. For the immunostaining, resolved proteins were first electrotransferred onto a polyvinyllidene difluoride (PVDF) membrane (Millipore, Eschborn, Germany) by semidry blotting using a $50 \mathrm{mM}$ Tris [tris(hydroxymethyl)-aminomethane] buffer containing $50 \mathrm{mM}$ boric acid and $10 \%$ methanol at $0.8 \mathrm{~mA} / \mathrm{cm}^{2}$ for 90 minutes at room temperature. Freeprotein binding sites of PVDF blots were blocked in Tris-buffered saline (TBS) containing $1 \%$ bovine serum albumin (BSA) and 1\% polyvinylpyrrolidone 40 for at least 6 hours at room temperature. Western blots were either incubated for 2 hours with obeche-specific polyclonal antibodies diluted 1:1000 in TBS containing 2\% 
BSA and $0.1 \%$ Tween 20 [polyoxyethylene (20) sorbitan monolaurate] to identify IgG-binding antigens, or they were incubated with human serum pool (diluted 1:4) to detect IgE-binding obeche-wood proteins. Nonspecific binding was eliminated using four 5-minute washings with $0.1 \%$ Tween 20 in TBS (TTBS). Specific IgG was detected by anti-rabbit IgG antibodies conjugated to alkaline phosphatase (Sigma, A3687) diluted 1:30 000 in $2 \% \mathrm{BSA}$ /TTBS. Specific human IgE was detected by anti-human IgE antibodies conjugated to alkaline phosphatase (Sigma, A3525, diluted 1:1000). Enzyme reactions were visualized by NBT/BCIP (nitroblue tetrazolium/5-bromo-4-chloro-3-indolyl phosphate) substrate tablets (Sigma).

\section{Dust sampling}

Airborne dust samples were taken from workplaces with a Gravicon VC 25 sampler (Ströhlein, Kaarst, Germany). The flow rate of the stationary sampler was $22.5 \mathrm{~m}^{3} /$ hour, and a sampling head was used for the inhalable dust fraction. Wood dust samples were collected from three companies during different work processes with obeche wood (multiple circular sawing, crosscut sawing, four-sided planing, and molding machine work). All of the machinery was encapsuled and fitted with an exhaust system. The Gravicon VC 25 sampler was installed in the operating area of the wood-processing machines, and the sampling time varied from 1 to 2.6 hours. The sampling heads were equipped with glass fiber filters (average retention capacity $=0.5 \mu \mathrm{m}, \mathrm{MN}$ 85/90 BF, diameter $150 \mathrm{~mm}$, Macherey-Nagel, Düren, Germany), which were weighed before and after the dust sampling on a high-precision scale, according to BGI 505-41 (13) at Holz-BG. For transport and storage, the filters were enclosed in dry plastic cassettes at room temperature. The total airborne dust concentration (milligrams per cubic meter) was calculated for the workplaces as the difference in the filter mass before and after the sampling (milligrams) divided by the total air volume (cubic meters).

\section{Filter extraction}

The optimal filter extraction methods were evaluated using a parallel sampler with glass fiber filters (type 85/90 BF, Macherey-Nagel, diameter $25 \mathrm{~mm}$ ) and varying elution buffers according to a protocol established during the European Union project "Measurement of Occupational Allergen Exposure" (MOCALEX) (14). In short, the parallel sampler (14) was placed in a provocation chamber, and different wood dusts (obeche, oak, ash, mahagony, teak, maple) were blown into the room and collected with a flow rate of $2 \mathrm{~m}^{3} /$ hour by 10 PAS- 6 sampling heads (Agricultural University, Wageningen,
Netherlands) in parallel. Filter samples were loaded, on the average, with $2-3 \mathrm{mg}$ of wood dust. The filters were extracted in $2.5 \mathrm{ml}$ of the extraction buffer by horizontal shaking for 3 hours, and the antigen content was measured in inhibition enzyme immunoassay. For the obeche wood proteins, an extraction buffer without additional detergent was the most effective.

Workplace samples, taken with a Gravicon VC 25 on glass fiber filters (MN 85/90 BF, diameter $150 \mathrm{~mm}$ ) with inhalable dust particles, were cut into pieces and transferred to a $50-\mathrm{ml}$ polypropylene tube (Nunc, Wiesbaden, Germany). A total of $20 \mathrm{ml}$ of PBS (200 mM sodium phosphate, $500 \mathrm{mM}$ sodium chloride, $\mathrm{pH}$ 7.4), and $10 \mathrm{ml}$ of Millipore-purified water was added, and the mix was incubated for 3 hours at room temperature on a horizontal mixer at full speed. Afterwards, insoluble components were separated by centrifugation $(3500 \mathrm{~g}$ for 25 minutes), and the clear supernatant (about $17 \mathrm{ml}$ ) was collected and lyophilized. The freeze-dried filter extracts were dissolved in a final concentration of $1 \mathrm{ml}$ of Millipore-purified water and were used to determine the protein content (Bradford assay) and to quantify the allergen content in an inhibition enzyme immunoassay.

\section{Quantification assay for obeche wood allergen}

For the quantification of the content of obeche wood allergen in the airborne particle fractions, an inhibition enzyme immunoassay was carried out. Wells of microtiter plates (Nunc) were coated with $2 \mu \mathrm{g}$ of obechewood-protein standard in $200 \mu \mathrm{l}$ of buffer $(0.1 \mathrm{M}$ sodium carbonate, $\mathrm{pH} 8.4$ ), and incubated overnight at $4^{\circ} \mathrm{C}$. Free binding sites were blocked with $250 \mu /$ well PBS containing 2\% BSA and $0.05 \%$ Tween 20 for 1.5 hours at room temperature. The microtiter plates were washed four times with PBS $/ 0.05 \%$ Tween 20 . The inhibition standard curve was established with $100 \mu$ of the standard obeche wood extract plus $100 \mu \mathrm{l}$ of obechewood-specific polyclonal antibodies. Filter extracts were processed in the same way by adding $100 \mu \mathrm{l}$ of the extract to $100 \mu \mathrm{l}$ of obeche-wood-specific antibodies. The mixture was transferred into an antigen-coated well, and the antibody-antigen interaction proceeded for 1.5 hours at room temperature during continuous shaking. The excessive antibody-inhibitor solution was removed by washing up to four times. Obeche-wood-specific antigen-antibody binding was detected by secondary antirabbit antibody conjugated to alkaline phosphatase (A-3678, lot no 123K6037, Sigma, dilution 1:10 000). After four final washes, the antibody binding was detected by the activity of alkaline phosphatase using p-nitrophenyl phosphate (Sigma Fast tablet, Sigma) as the substrate. The substrate development was measured after 60 minutes, at an optical density of $405 \mathrm{~nm}$ with an enzyme immunoassay reader (Spectramax Plus 384, 


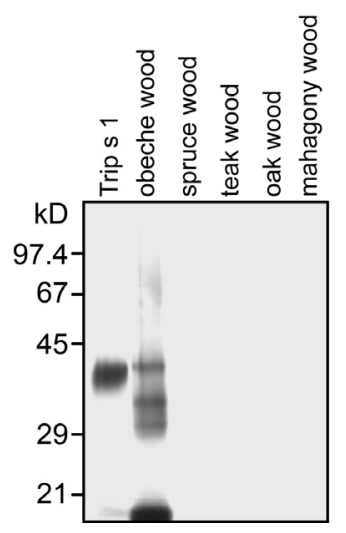

Figure 1. Antigen profile for polyclonal antibodies specific for obeche: an immunoglobulin $\mathrm{G}$ blot of purified obeche wood allergen Trip $\mathrm{s} 1$ and different wood (obeche, spruce, teak, oak, and mahagony) extracts incubated with the polyclonal antibodies specific for obeche wood.

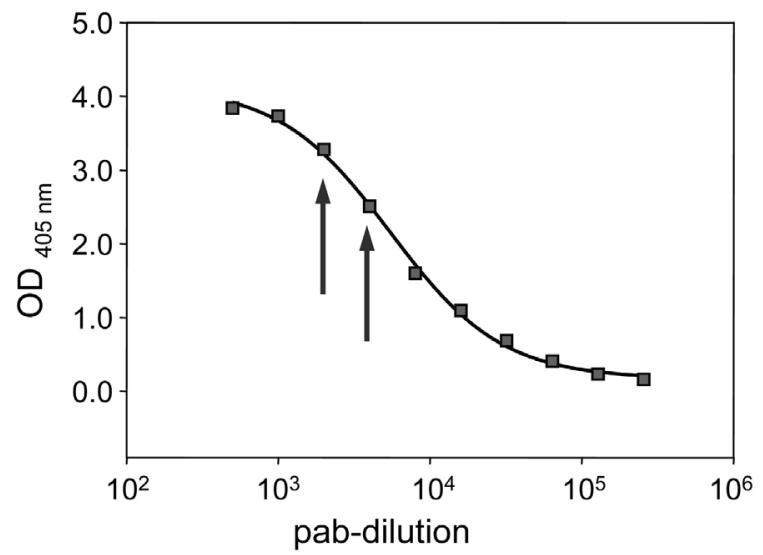

Figure 2. Polyclonal antibodies (pab) titration specific for obeche. Enzyme immunoassay (EIA) of polyclonal antibodies specific for obeche wood on standardized obeche wood extract from dilution 1:500 in double steps up to 1:258 000. Arrows indicate dilutions 1:2000 and $1: 4000$ of polyclonal antibodies, which were chosen for inhibition EIA assembling. (OD = optical density)

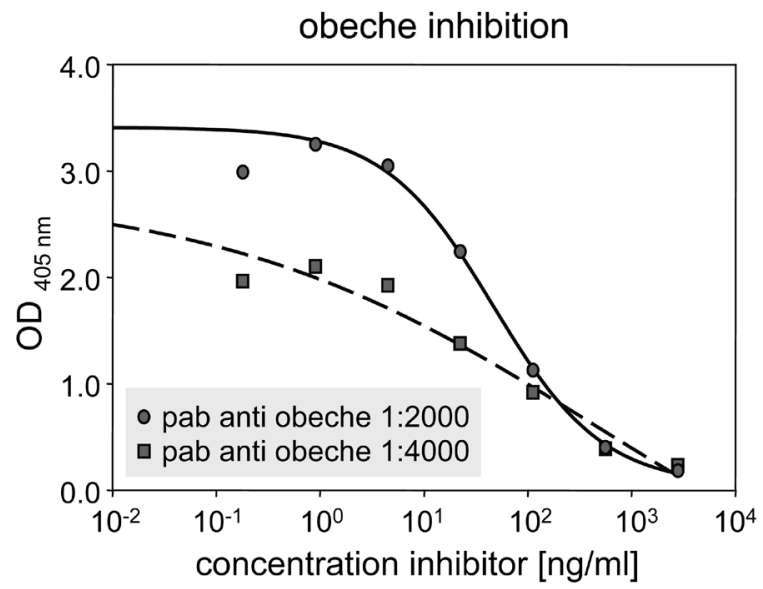

Figure 3. Inhibition enzyme immunoassay with two different dilutions of polyclonal antibodies (pab) (1:2000 and 1:4000) and increasing inhibitor concentrations. (OD = optical density)
Molecular Devices, Ismaning, Germany), and the results were processed with SoftmaxPro software (version 4.7, Molecular Devices Corporation, Sunnyvale, CA, USA) using a four-parameter fit.

The coefficient of variation was calculated as the standard deviation multiplied by 100 divided by the mean value for three concentrations of obeche wood antigen (calculated as 25,50 , and $100 \mathrm{ng} / \mathrm{ml}$ ). The intraassay coefficient of variation was calculated as the mean value from the double values taken from four assays for three concentrations (the intraassay coefficient of variation was calculated as the mean value of 12 double values). The interassay coefficient of variation was calculated from four tests with three different antigen concentrations.

\section{Statistical analysis}

Analyses of the data (analysis of variance) were performed with a one-way Tukey's multiple comparison test with GraphPad Prism (GraphPad Software Inc, San Diego, CA, USA). The significance has been given for values with $\mathrm{P}<0.05$.

\section{Results}

\section{Development of the antigen quantification assay}

The quantification test for obeche wood allergen was developed as an inhibition enzyme immunoassay based on a polyclonal rabbit serum. The IgG-binding profile of the rabbit serum was tested in immunoblots with different wood extracts (figure 1). The purified major obeche wood allergen Trip s 1 was detected at $38 \mathrm{kD}$. Altogether, four antigens were recognized in the crude obeche wood extract, Trip s 1, and additional antigens of 14,28 , and $30 \mathrm{kD}$. There was no cross-reactivity to other wood species like spruce, teak, oak, or mahagony.

The optimal antibody dilution was determined by titration of the serum starting from a dilution factor of 1:500, using double steps to 1:128 000 (figure 2). The linear range of the dilution curve was between a dilution factor of 1:1000 and a factor of 1:16 000; two dilutions, 1:2000 and 1:4000 in the upper linear range, were chosen for developing the inhibition test. For the inhibition enzyme immunoassay, increasing concentrations of standardized obeche wood extract $(0.9 \mathrm{ng} / \mathrm{ml}$ in fivefold steps up to $2800 \mathrm{ng} / \mathrm{ml}$ ) were mixed with antibodies in both dilutions (figure 3 ). The dilution of polyclonal antibodies of 1:2000 showed a steeper inhibition curve and was used for the experiments. The measuring range of the assay quantifying obeche wood was established to be between $20 \%$ and $80 \%$ inhibition. Accordingly, samples with antigen concentrations between $30 \mathrm{ng} / \mathrm{ml}$ and 


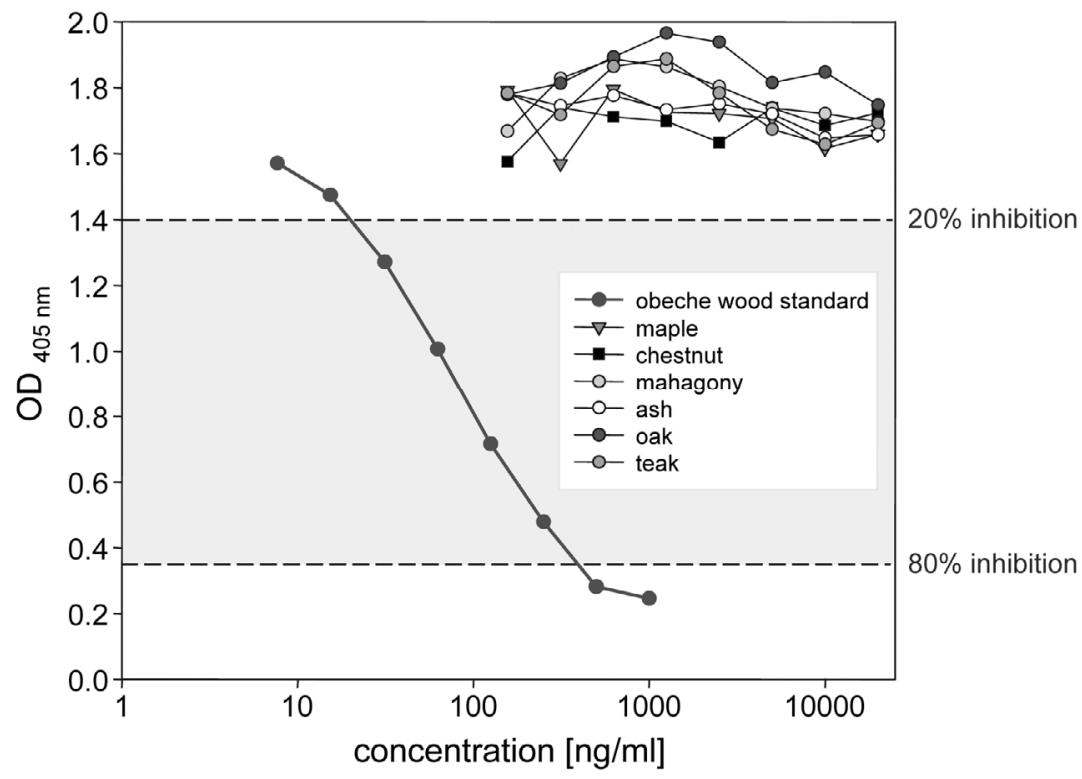

Figure 4. Inhibition curve of polyclonal antibodies specific for obeche wood (1:2000) with different obeche wood antigen concentrations. The measured absorption for each obeche wood antigen concentration was connected to generate a standard curve in an inhibition enzyme immunoassay. Cross-reactions to other wood species (maple, chestnut, mahagony, ash, oak, and teak) were tested with high loaded (100-1000 mg) filter extracts of wood dust. (OD = optical density)

Table 1. Assessment of obeche wood allergen at the exposed workplaces.

\begin{tabular}{|c|c|c|c|c|c|c|c|c|c|c|c|c|c|c|c|c|}
\hline & & \multicolumn{3}{|c|}{ Processed wood } & \multicolumn{3}{|c|}{ Dust sample } & \multicolumn{3}{|c|}{ Airborne dust ${ }^{\mathrm{a}}$} & \multicolumn{3}{|c|}{ Protein } & \multicolumn{3}{|c|}{ Allergen } \\
\hline & & $\begin{array}{l}\text { Weight } \\
\text { (mg) }\end{array}$ & Mean & SD & $\begin{array}{c}\text { Concen } \\
\text { tration } \\
\left(\mathrm{mg} / \mathrm{m}^{3}\right)\end{array}$ & Mean & SD & $\begin{array}{c}\text { Concen- } \\
\text { tration } \\
(\mu \mathrm{g} / \mathrm{mg})\end{array}$ & Mean & SD & $\begin{array}{c}\text { Concen- } \\
\text { tration } \\
(\mathrm{ng} / \mathrm{mg})\end{array}$ & Mean & SD & $\begin{array}{c}\text { Air con- } \\
\text { centra } \\
\text { tion } \\
\left(\mathrm{ng} / \mathrm{m}^{3}\right)\end{array}$ & Mean & SD \\
\hline \multicolumn{2}{|l|}{ Company I } & $\cdot$ & 20.7 & 13.6 & $\cdot$ & 0.39 & 0.23 & $\cdot$ & 6.3 & 3.2 & $\cdot$ & 23.1 & 5.8 & $\cdot$ & 8.8 & 4.3 \\
\hline Filter 1 & Wawa & 38.9 & . & . & 0.70 & . & . & 2.6 & . & . & 20.0 & . & . & 14.0 & . & . \\
\hline Filter 2 & Wawa & 37.2 & . & . & 0.67 & . & . & 2.7 & . & . & 20.0 & . & . & 13.4 & . & . \\
\hline Filter 3 & Wawa & 10.7 & . & . & 0.22 & . & . & 7.9 & . & . & 15.3 & . & . & 3.4 & . & . \\
\hline Filter 4 & Wawa & 9.9 & . & . & 0.20 & . & . & 10.8 & . & . & 25.8 & . & . & 5.2 & . & . \\
\hline Filter 5 & Wawa & 14.5 & . & . & 0.31 & . & . & 6.9 & . & . & 31.4 & . & . & 9.7 & . & . \\
\hline Filter 6 & Wawa & 12.8 & $\cdot$ & $\cdot$ & 0.27 & $\cdot$ & · & 7.0 & $\cdot$ & . & 26.1 & $\cdot$ & $\cdot$ & 7.0 & $\cdot$ & . \\
\hline \multicolumn{2}{|c|}{ Company II } & $\cdot$ & 59.8 & 31.2 & $\cdot$ & 2.27 & 1.61 & $\cdot$ & 1.1 & 0.3 & $\cdot$ & 4.0 & 0.4 & $\cdot$ & 9.4 & 7.3 \\
\hline Filter 7 & Ayous & 92.6 & . & . & 3.92 & . & . & 0.9 & . & . & 4.6 & . & . & 18.1 & . & . \\
\hline Filter 8 & Ayous & 79.7 & . & . & 3.37 & . & . & 0.8 & . & . & 3.8 & . & . & 12.8 & . & . \\
\hline Filter 9 & Ayous & 38.9 & . & . & 1.04 & . & . & 1.1 & . & . & 3.8 & . & . & 3.9 & . & . \\
\hline Filter 10 & Ayous & 27.8 & $\cdot$ & . & 0.74 & $\cdot$ & . & 1.5 & . & $\cdot$ & 3.9 & . & $\cdot$ & 2.9 & . & . \\
\hline \multicolumn{2}{|c|}{ Company III } & . & 52.9 & 12.7 & · & 1.09 & 0.20 & . & 4.7 & 0.9 & . & 20.4 & 2.8 & . & 22.3 & 5.0 \\
\hline Filter 11 & Ayous & 50.9 & . & . & 1.29 & . & . & 5.4 & . & . & 22.2 & . & . & 28.7 & . & . \\
\hline Filter 12 & Ayous & 41.2 & . & . & 1.05 & . & . & 5.5 & . & . & 22.4 & . & . & 23.5 & . & . \\
\hline Filter 13 & Ayous & 70.9 & . & . & 1.21 & . & . & 3.6 & . & . & 16.5 & . & . & 19.9 & . & . \\
\hline Filter 14 & Ayous & 48.5 & . & . & 0.83 & . & . & 4.4 & . & . & 20.7 & . & . & 17.2 & . & . \\
\hline
\end{tabular}

a The airborne dust concentration was calculated as the weight of the dust sample $(\mathrm{mg})$ divided by the sampled air volume $\left(\mathrm{m}^{3}\right)$.

$300 \mathrm{ng} / \mathrm{ml}$ could be quantified (figure 4). Test specificity was proved with a variety of wood dust samples (maple, chestnut, mahagony, ash, oak, and teak), which were applied in high concentrations [up to $1000 \mu \mathrm{g}$ of wood dust per milliliter (figure 4)]. There was no inhibition of the polyclonal antibodies specific for obeche by other wood dusts. The mean intraassay coefficient of variation of the double estimations was $4.7 \%$ for 24 samples. The interassay coefficient of variation was calculated from four tests at three different antigen concentrations. The coefficient of variation for the low concentration (25 ng/ml) was 23.91, that of the medium concentration
(50 ng/ml) was 23.27, and that of the high concentration (100 ng/ml) was 17.23. As such, the mean interassay coefficient of variation was calculated as $21.5 \%$.

\section{Allergen measurement at exposed workplaces}

Allergens were measured with a stationary sampler in three wood-processing companies (table 1) in which the predominantly processed wood was obeche. In company I, 95\% of the supplied obeche wood was imported from Ghana, where it is called wawa. Companies II and III worked exclusively with obeche wood from Cameroon, 
called ayous. Wawa and ayous are not used as trade names, but are used to denote the geographic origin of the obeche wood. Airborne inhalable dust was collected at different workplaces during the planning and sawing processes. The protein content of the samples from company I had an average concentration of $6.3 \mu \mathrm{g} / \mathrm{mg}$, which was significantly $(\mathrm{P}<0.05)$ higher than in company II $(1.1 \mu \mathrm{g} / \mathrm{mg})$, but was not statistically higher than in company III $(4.7 \mu \mathrm{g} / \mathrm{mg})$. The allergen content per milligram of dust from company II was $4.0 \mathrm{ng} / \mathrm{mg}$, which was significantly $(\mathrm{P}<0.05)$ lower than in company I $(23.1 \mathrm{ng} / \mathrm{mg})$ and company III $(20.4 \mathrm{ng} / \mathrm{mg})$. With

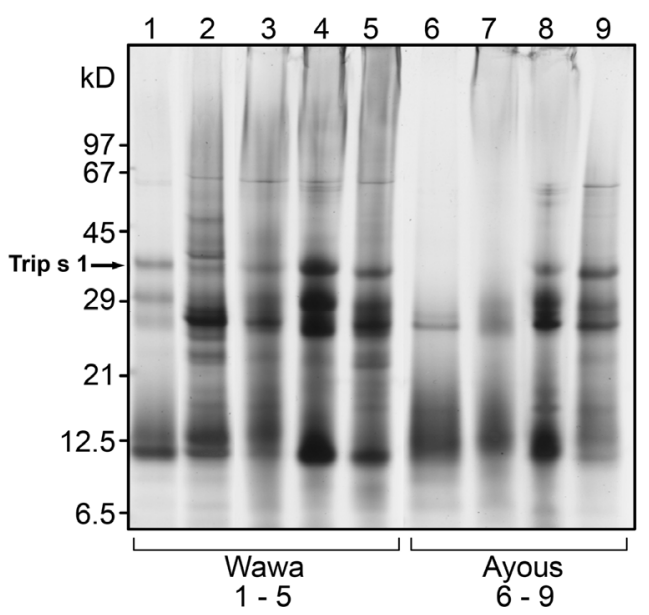

Figure 5. SDS-PAGE (sodium dodecyl sulfate-polyacrylamide gel electrophoresis) silver stain of the protein pattern of wawa (lanes 1-5) and ayous (lanes 6-9) obeche wood. Wood dust samples were partially taken in parallel to the following filter samples: $1+2$ : wawa samples from company I; 3 : wawa sample from an external wood shop; $4+5$ : certified wawa wood (standard); 6+7: ayous samples from company II; 8+9: ayous samples from company III. respect to the allergen concentrations in the air, company III had the highest ambient allergen concentration, with an average of $22.3 \mathrm{ng} / \mathrm{m}^{3}$. This value was statistically significant $(\mathrm{P}<0.05)$ when compared with that of company I $\left(8.8 \mathrm{ng} / \mathrm{m}^{3}\right)$ and company II $\left(9.4 \mathrm{ng} / \mathrm{m}^{3}\right)$.

While the highest dust exposure was measured in company II, the highest allergen exposure values were obtained from company III.

\section{Analysis of allergens in different obeche wood samples}

To evaluate the variability of the allergen amount in obeche wood, the protein profile of different wawa and ayous wood samples were analyzed by SDS-PAGE (figure 5). All of the wood samples were applied with the same amount of $1 \mu \mathrm{g}$ of protein per lane. The typical obeche wood protein triplet of 28,30 , and $38 \mathrm{kD}$ appeared in more or less all of the five wawa wood samples (lanes 1-5) and in two of the ayous wood samples (lanes 8 and 9). The ayous wood samples from company II (lanes 6 and 7) showed protein bands at only 28 and $12 \mathrm{kD}$; the major allergen of $38 \mathrm{kD}$ (Trip s 1) and the $30 \mathrm{kD}$ protein were missing. In contrast, the ayous samples from company III exhibited a typical obeche wood protein triplet of 28,30 , and $38 \mathrm{kD}$. Both woods, wawa and ayous, showed a prominent protein band at $12 \mathrm{kD}$.

Corresponding immunoblots were incubated with polyclonal antibodies (IgG) specific for obeche wood and with pooled human sera (IgE) (figure 6).

Polyclonal rabbit serum recognized (figure $6 \mathrm{~A}$ ) the major allergen Trip s 1 and an additional $12 \mathrm{kD}$ protein in all of the wawa wood samples (lanes 1-5) and in two ayous wood samples (lanes 8 and 9). Obeche wood

A
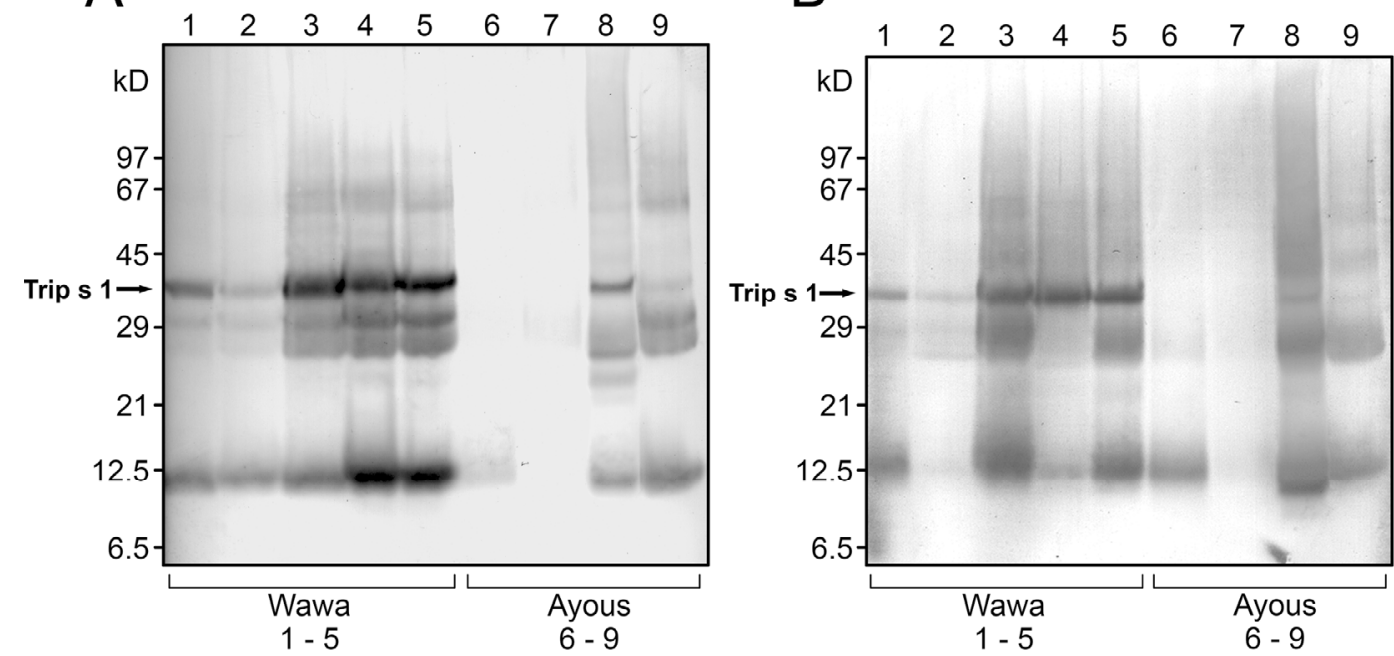

Figure 6. Rabbit immunoglobulin (Ig) $G$ antigen profile (A) and human $\lg E$ antigen profile (B) on immunoblots of wawa and ayous wood samples. Both blots were prepared with ayous and wawa wood extracts corresponding to the silver-stained protein profiles in figure 5. Each lane was loaded with $2.5 \mu \mathrm{g}$ of protein. Arrows label the molecular weight of Trip s 1 at $38 \mathrm{kD}$. 
proteins of 28 and $30 \mathrm{kD}$ were labeled intensively in three of the five wawa samples (lanes 3-5) and less intensively in the wawa samples from company I (lanes 1 and 2) and ayous wood samples from company II (lanes 8 and 9).

The IgE-binding patterns of the wawa and ayous samples showed a profile similar to that of polyclonal antibodies (figure 6 B). Trip s 1 was recovered from all of the wawa samples (lanes 1-5), but less intensively from the ayous wood samples from company III (lanes 8 and 9). The ayous wood samples from company II did not exhibit Trip s 1. IgE binding was also found for the $12 \mathrm{kD}$ protein, as well as for 28 and $30 \mathrm{kD}$ antigens in both the wawa and ayous wood samples. Both blot studies supported the finding that the Trip s 1 content was reduced in ayous wood when compared with the content in wawa wood, and this finding may be one reason for the lower allergen content in the wood material processed in company II.

\section{Discussion}

We developed a quantification test to assess the allergen concentration of obeche wood at exposed workplaces. The assay, based on polyclonal antibodies, was highly specific for obeche wood allergens. Cross-reactivity to other wood species was not observed. The detection range of the assay covered allergen concentrations from 30 to $300 \mathrm{ng} / \mathrm{ml}$ in wood dust extract and was sufficient for measuring the airborne content of obeche wood allergen at exposed workplaces. Via back-calculation, 1 milligram of wood dust is sufficient to quantify the allergen content in a sample. The inhibition enzyme immunoassay for obeche wood allergen had an intraassay coefficient of variation of $4.7 \%$ and an interassay coefficient of variation of $21.5 \%$, values in the range of other described allergen quantification tests (15-21).

Immunologic quantification systems are based mainly on the following three different types of antibodies: human $\mathrm{IgE}$ antibodies/IgG4 antibodies $(15,16)$, mouse monoclonal antibodies $(17,18)$, or polyclonal antibodies (19-21) assembled in a direct enzyme immunoassay, competitive inhibition enzyme immunoassay, or sandwich enzyme immunoassay, depending on the desired test sensitivity and the kind of target (single antigen or complex antigen mixture). Test systems with human IgE antibodies have a great advantage for more or less known allergen sources like wood dust, since they detect only IgE-binding antigens, which form the class of allergenic proteins. However, the recognized allergen pattern must be representative and the human test serum must be available in high amounts to ensure reproducibility. Furthermore, cross-reactions from other allergenic sources should be excluded to warrant test specificity. Monoclonal mouse antibodies are highly specific for one single antigen, but, for the quantification of several antigens, a mixture of different specific monoclonal antibodies would be necessary. In addition, monoclonal antibody production is both time- and costconsuming. With the intention of measuring a maximal range of obeche wood antigens, including the major allergen Trip s 1, we decided to use a polyclonal rabbit serum directed against obeche wood extract. Polyclonal antibodies recognize several epitopes on different antigens and enable numerous obeche wood antigens to be detected. Therefore, it is possible to detect obeche wood antigens in very low amounts and with high sensitivity. Of course, it has to be kept in mind that not all antigens detected by polyclonal antibodies are allergens. However, for the obeche-specific polyclonal antibodies, the binding pattern was similar to the $\mathrm{IgE}$ binding of patient serum pools. The major obeche wood allergen Trip s 1 , as well as three other antigens (12, 28 and $30 \mathrm{kD})$, were specifically recognized by this polyclonal serum. The $28 \mathrm{kD}$ protein has been described as an IgE-binding obeche allergen by two Spanish research groups $(9$, 10). The 12 and $30 \mathrm{kD}$ IgE-binding proteins have not been described previously, but, in a former study (12), a $14 \mathrm{kD}$ chitin-binding protein was mentioned; it had been recognized as an allergen in 3 of the 14 tested persons for obeche wood allergy.

In addition to test sensitivity, standardized extraction conditions for wood dust filters are important. Optimal filter preparation was performed according to the MOCALEX project (14). In contrast to the reported results for wheat allergen extraction from airborne dust samples, the addition of detergent did not improve the recovery of obeche wood allergens (data not shown). This finding supports the former finding that obeche wood proteins needed only aqueous extraction conditions in contrast to other woods (22).

Regarding the discussion of health-based exposure limits for wood dust, it should be noted that the total dust concentration does not seem to be the most valid tool for assessing the risk for wood workers with respect to sensitization. Our results demonstrate the significant differences in airborne allergen concentrations in comparison with dust concentrations, depending on the processed obeche wood (table 1). Similar observations have already been described by Teschke et al (23), who found that the diversity of inhalable wood dust particles depend on the age of the wood material (green wood versus stored wood), tree species, and processing jobs. Moreover, the discussion of methodical aspects of wood dust sampling, like particle size and personal versus stationary sampling, was controversial in regard to the maximal exposure limits (24-29). In terms of the personal inhalable dust exposure associated with 
occupational exposure limits, the approved method for measuring wood dust concentrations is personal sampling. In our study, stationary samples were taken from three workplaces (about 2 meters from the wood-processing machine) to measure the airborne concentration of wood allergens. Nevertheless, it would be more informative to have obtained personal samples for individual occupational exposure, but the primary aim of this study was to validate the assay for obeche wood allergen under field conditions and not to determine personal exposure. For this purpose, stationary samples were more practical. The measured wood dust concentration varied in the three investigated companies, and, in company II, wood dust concentrations of $>3 \mathrm{mg} / \mathrm{m}^{3}$ also exceeded the German occupational exposure limit of $2 \mathrm{mg} / \mathrm{m}^{3}$ (29). After an occupational exposure limit of $0.5 \mathrm{mg} / \mathrm{m}^{3}$, as proposed by the Scientific Committee for Occupational Exposure Limits, is taken into consideration, companies II and III had concentrations above the limit, and the levels in company I also exceeded the limit. In the three companies monitored at special work processes, there was obviously not a possibility to maintain airborne concentrations of wood dust below $0.5 \mathrm{mg} / \mathrm{m}^{3}$, even though all of the machines had an exhaust system. Using an allergen quantification assay, we had the opportunity to prove the importance of the recommended limit with regard to IgE-mediated sensitization. The inhibition enzyme immunoassay allowed the concentration of obeche wood allergen to be determined at the workplace independently of the wood dust concentration. Therefore, occupational workplace conditions could be optimized by monitoring the efficiency of measures for wood allergen reduction.

The quantification assay for obeche wood and comparable immunoblots showed different allergen contents in workplace samples, in some cases associated with the geographic origin of the wood [Ghana (wawa) versus Cameroon (ayous)]. According to the detection method for IgE-binding proteins with a human serum pool $(\mathrm{N}=6)$ diluted 1:4 with buffer, it may be possible that allergens recognized by only one serum are not visualized on the blot membrane. The diluted serum pool thus detected only major allergen bands. This finding suggests that the different allergen contents may be attributed to the missing or reduced Trip s 1 in some samples of ayous wood. Additional evidence for a possible variability in the allergenic potency of obeche wood was provided by the experiences of the wood workers, who pointed out that processing wawa wood resulted in more adverse respiratory effects than working with ayous wood. Of course, these findings are only indications of different allergen contents in geographically diverse obeche wood species, but it should be taken into consideration that obeche wood materials can be highly variable in regard to allergen content.
In conclusion, with the inhibition enzyme immunoassay, the airborne obeche wood allergen exposure in wood-processing companies can be monitored. The total dust concentration at workplaces with exposure to obeche wood dust did not correspond with the assessed allergen concentrations and is therefore not a suitable tool for determining exposure limits regarding sensitization risk. The allergen pattern of different obeche wood samples varied, and the major allergen Trip s 1 was predominantly detected in wood samples from Ghana.

\section{Acknowledgments}

This study was supported by Hauptverband der Berufsgenossenschaften (HVBG), Sankt Augustin, Germany, as project All/Med 9.

We thank Silke Maryska, Christina Fleischer, Eva Zahradnik, and Bernd Naurath for their excellent technical support.

\section{References}

1. Douwes J, McLean D, Slater T, Pearce N. Asthma and other respiratory symptoms in New Zealand pine processing sawmill workers. Am J Ind Med. 2001;39:608-15.

2. Kauppinen T, Vincent R, Liukkonen T, Grzebyk M, Kauppinen A, Welling I, et al. Occupational exposure to inhalable wood dust in the member states of the European Union. Ann Occup Hyg. 2006;50:549-61.

3. Schlünssen V, Schaumburg I, Taudorf E, Mikkelsen AB, Sigsgaard T. Respiratory symptoms and lung function among Danish woodworkers. J Occup Environ Med. 2002;44:82-98.

4. Skovsted TA, Schlünssen V, Schaumburg I, Wang P, Skov PS. Hypersensitivity to wood dust. Allergy. 2000;55:1089-90.

5. Schulze J, Brüning T, Donhuijsen K, Kleine H, Pesch B, Raulf-Heimsoth $\mathrm{M}$, et al. Comments on the recommendation of the Scientific Committee on Occupational Exposure Limits (SCOEL) for wood dust. Air Qual Control. 2003;63:99-104.

6. Brisman J, Järvholm B, Lillienberg L. Exposure-response relations for self reported asthma and rhinitis in bakers. Occup Environ Med. 2000;57:335-40.

7. Hytönen M, Kanerva L, Malmberg H, Martikainen R, Mutanen $\mathrm{P}$, Toikkanen J. The risk of occupational rhinitis. Int Arch Occup Environ Health. 1997;69:487-90.

8. Scadding GK. Further marches: allergic and non-allergic. Clin Exp Allergy. 2007;37:485-7.

9. Ferrer A, Maranon F, Casanovas M, Fernandez-Caldas E. Asthma from inhalation of Triplochiton scleroxylon (samba) wood dust. J Invest Allergol Clin Immunol. 2001;11:199-203.

10. Quirce S, Hinojosa M, Maranon F, Ferrer A, Fernandez-Caldas E, Sastre J. Identification of obeche wood (Triplochiton scleroxylon) allergens associated with occupational asthma. J Allergy Clin Immunol. 2000;106:400-1.

11. Hausen BM. Sensitizing capacity of naturally occurring quinones: 5.2.6-dimethoxy-p-benzoquinone-occurrence and significance as a contact allergen. Contact Dermatitis. 
1978;4:204-13.

12. Kespohl S, Sander I, Merget R, Petersen A, Meyer HE, Sickmann A, et al. Identification of an obeche (Triplochiton scleroxylon) wood allergen as a class I chitinase. Allergy. 2005;60:808-14

13. BGI 505-41: Bestimmung von Holzstaub, 1/1989. [Regulations on wood dust, 1/1989]. Köln (Germany): Carl Heymanns Verlag GmbH; 1989.

14. Bogdanovic J, Wouters IM, Sander I, Zahradnik E, Harris-Roberts J, Rodrigo MJ, et al. Airborne exposure to wheat allergens: optimised elution for airborne dust samples. J Environ Monit 2006;8:1043-8.

15. Bogdanovic J, Wouters IM, Sander I, Raulf-Heimsoth M, Elms J, Rodrigo MJ, et al. Airborne exposure to wheat allergens: measurement by human immunoglobulin G4 and rabbit immunoglobulin G immunoassays. Clin Exp Allergy. 2006;36:1168-75.

16. Gordon S, Tee RD, Nieuwenhuijsen MJ, Lowson D, Harris J, Taylor AJN. Measurement of airborne rat urinary allergen in an epidemiologic-study. Clin Exp Allergy. 1994;24:1070-7.

17. Raulf-Heimsoth M, Sander I, Chen ZP, Borowitzki G, Diewald $\mathrm{K}$, van Kampen V, et al. Development of a monoclonal antibody-based sandwich ELISA for detection of the latex allergen Hev b 1. Int Arch Allergy Immunol. 2000;123:236-41.

18. Sander I, Neuhaus-Schroder C, Borowitzki G, Baur X, RaulfHeimsoth M. Development of a two-site enzyme-linked immunosorbent assay for alpha-amylase from Aspergillus oryzae based on monoclonal antibodies. J Immunol Methods. 1997;210:93-101.

19. Gómez-Ollés S, Cruz MJ, Renström A, Doekes G, Morell F, Rodrigo MJ. An amplified sandwich EIA for the measurement of soy aeroallergens. Clin Exp Allergy. 2006;36:1176-83.
20. Lillienberg L, Baur X, Doekes G, Belin L, Raulf-Heimsoth M, Sander I, et al. Comparison of four methods to assess fungal alpha-amylase in flour dust. Ann Occup Hyg. 2000;44:427-33.

21. Sander I, Raulf-Heimsoth M. Exposure assessment of allergenic enzymes in workplaces. Air Qual Control. 2001;61:31923.

22. Gruehn S, Sander I, Maryska S, Flagge A, Bruening T, RaulfHeimsoth M. Identification of obeche wood (Triplochiton scleroxylon) allergens as basis for a more standardized diagnostic. Allergy. 2002;57:109.

23. Teschke K, Demers PA, Davies HW, Kennedy SM, Marion SA, Leung V. Determinants of exposure to inhalable particulate, wood dust, resin acids, and monoterpenes in a lumber mill environment. Ann Occup Hyg. 1999;43:247-55.

24. Burstyn I, Teschke K. Studying the determinants of exposure: a review of methods. AIHA J. 1999;60:57-72.

25. Harper M, Muller BS, Al B. Determining particle size distributions in the inhalable size range for wood dust collected by air samplers. J Environ Monit. 2002;4:642-7.

26. Harper M, Muller BS. An evaluation of total and inhalable samplers for the collection of wood dust in three wood products industries. J Environ Monit. 2002;4:648-56.

27. Harper M, Akbar MZ, Andrew ME. Comparison of wood-dust aerosol size-distributions collected by air samplers. J Environ Monit. 2004;6:18-22.

28. Renström A. Exposure to airborne allergens: a review of sampling methods. J Environ Monit. 2002;4:619-22.

29. Poppe M, Detering B, Neuschaefer-Rube J, Woeste W, Wüstefeld B, Wolf J. Workplace exposure to wood dust in the woodworking industry. Air Qual Control. 2002;62:247-57.

Received for publication 5 November 2007 